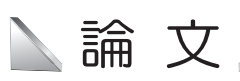

Original Paper

\title{
札棍軟石の繰返し一次元凍結融解実験 *
}

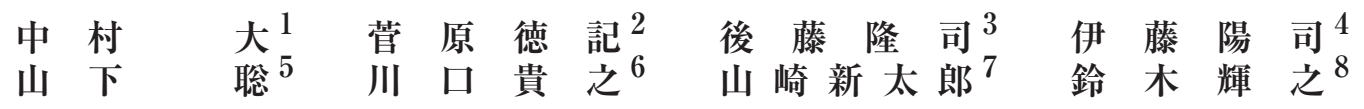

\section{Repeated One-Dimensional Freeze-Thaw Experiments on Sapporo Soft Rock}

\author{
by Dai NAKAMURA ${ }^{a^{*}}$, Yoshiki SUGAWARA ${ }^{\mathrm{b}}$, Takashi GOTO ${ }^{\mathrm{c}}$, Yoji ITO ${ }^{\mathrm{c}}$, Satoshi YAMASHITA ${ }^{\mathrm{d}}$, \\ Takayuki KAWAGUCHI ${ }^{\mathrm{c}}$, Shintaro YAMASAKI ${ }^{\mathrm{a}}$ and Teruyuki SUZUKI ${ }^{\mathrm{e}}$
}

a. Research Associate, Department of Civil and Environmental Engineering, Kitami Institute of Technology, Koen-cho 165, Kitami, 090-8507 JAPAN (*Corresponding author E-mai: dnaka@, mail.kitami-it.ac.jp)

b. East Japan Railway Morioka Branch, Technical Center Track Maintenance, Morioka Ekimae Dori 1-41, Morioka, 020-0034 JAPAN

c. Associate Professor, Department of Civil and Environmental Engineering, Kitami Institute of Technology

d. Professor, Department of Civil and Environmental Engineering, Kitami Institute of Technology

e. Professor Emeritus, Department of Civil and Environmental Engineering, Kitami Institute of Technology

In this research the behavior of Sapporo soft rock was investigated under the effect of repeated one-dimensional freeze-thaw. As indicators of the rate of deterioration, the AE (Acoustic Emissions), porosity, and elastic wave velocity under dry conditions were used. It is considered that the microscopic destruction that occurred inside Sapporo soft rock, which doesn't show significant effect of freezing, can be analyzed in detail by measuring the AE.

Main results obtained in our research are summarized as follows:

(1) No deterioration of the test pieces was apparently observed even after 40 cycles of one-dimensional freeze-thaw. This experimental result implies that the effects of one-dimensional freezing on rock are significantly different from those resulting from three-dimensional freezing.

(2) It was observed that the total number of occurrences of $\mathrm{AE}$ was the highest in the first cycle of freezethaw, and decreased thereafter. However, the number was converging to an almost constant value.

(3) It was confirmed that the number of occurrences of AE decreased during freezing (processes 1, 2, and 3) after several freeze-thaw cycles, but increased during thawing (process 4).

(4) It was confirmed that the displacement of expansion during freezing and shrinking during thawing increased with repetition of the freeze-thaw cycle. The increase in the number of occurrences of AE during thawing mentioned above was due to this increase in the displacement of shrinking during thawing.

The mechanism of deterioration caused by one-dimensional freeze-thaw on Sapporo soft rock revealed in this research is of great value in engineering for the examination of methods for the maintenance of architecture made of Sapporo soft rock, which is currently being re-evaluated as historical architecture.

KEY WORDS: Sapporo Soft Rock, Freeze-Thaw, Frost Heave, AE, Elastic Wave Velocity, Porosity

\section{1. は じめに}

札幌軟石 ( 支笏溶結凝灰岩) は, 札幌や小樽を中心に, 建築・ 土木材料として広く用いられてきた。明治初期から昭和初期にか

*2011 年 3 月 25 日受付 2011 年 8 月 17 日受理

1. 正会員 北見工業大学 工学部社会環境工学科 助教

2. JR 東日本盛岡支社盛岡保線技術センター

3. 正会員 北見工業大学工学部社会環境工学科准教授

4. 正会員 北見工業大学 工学部社会環境工学科准教授

5. 北見工業大学 工学部社会環境工学科教授

6. 北見工業大学工学部社会環境工学科准教授

7. 北見工業大学工学部社会環境工学科助教

8. 北見工業大学 工学部社会環境工学科名誉教授

[ 著者連絡先 ] FAX: 0157-23-9408 (北見工業大学・中村)

E-mail:dnaka@mail.kitami-it.ac.jp

キーワード : 札幌軟石, 凍結融解, 凍上, $\mathrm{AE}$, 弹性波速度, 空隙率
けて, 多くの札幌軟石建築物が建設されたが, 都市の近代化に伴 い，大規模な建築物の多くは姿を消しつつある。しかしながら， 住宅付属倉庫や質蔵等として, 数多く建設された小規模な石造の 倉庫は，現在でも市街地に点在しており，店舗等へと用途を変え て，再利用されているものも多い。また，歴史的建築物としての 価値も再評価されており，札幌の貴重な財産であるという認識も 広がりつつある。

ただし, 北海道のような寒冷地において, 札幌軟石のような多 孔質材料を使用する場合，屋外で低温（マイナスの温度）に曝さ れるため, 必ず凍結による劣化という問題が付きまとう。例えば, 高見ら ${ }^{1)}$ は, 北海道札幌市, 北海道開拓の村に移設された旧小 樽新聞社で発生した凍害について報告している。この建築物の外 壁は積み上げた札幌軟石で構成されており, その南向き壁面にお 
いて顕著な劣化が確認された。高見ら ${ }^{1)}$ は, この劣化が，南向 き壁面の凍結融解回数の多さと, 過酷な温度条件によって引き起 こされたと結論付けている。また, 同新聞社については, 福田 ${ }^{2)}$ も調査を行っており，北向き壁面に設置したセンサで，3月中旬 から下旬にかけて, 凍害に関わると思われる温度変動が出現して いることを報告している。

陳ら ${ }^{3)}$ は，札幌軟石の三次元凍結融解実験を繰返し行い，そ の劣化の様子を詳細に観察した。この実験の結果, 十数サイクル の凍結融解後, 供試体に亀裂が発生し, その亀裂は凍結融解を重 ねるごとに, 伸展していくことが確認された。三次元凍結融解実 験では, 岩石が周辺部から凍結していくため, 間隙水が岩石の中 央部分で閉塞された状態となる。この間隙水が凍結する際に発生 する体積膨張によって, 岩石の中央部分に亀裂が発生する。この ように, 三次元凍結融解実験は供試体の全面から冷気をあてて凍 結を行うという手法で行われるため, 実際の自然環境下における 凍結融解とはかけ離れた実験条件となってしまっていると考えら れる。

また，小玉ら ${ }^{4)}$ は，札幌軟石を含む 5 種類の岩石を用いて，2 種類の凍結破壊機構を想定した実験を行い, 間隙水の凍結に伴う 岩石の変形挙動について, 詳細な検討を行っている。

1 つめは，岩石中に間隙水が生成されることによって，逃げ場 を失った水点下でも残存する間隙水 (不凍水) の圧力が上昇し, 微視的な破壊が進行するケース ( 以下,「その場凍結」と呼ぶ) である。小玉らは「その場凍結」を想定して一次元凍結融解実験 を行っており, 札幌軟石を用いた実験では, 凍結融解の 1 サイク ル目に, 供試体中央部分に破断面が形成されたことを報告してい る。小玉らの凍結手法は, 供試体の上下端面の温度を独立したぺ デスタルで一定の温度差で低下させていくというものである。こ の手法では，供試体は上下 2 方向から泠却されることとなり，供 試体の中央部分が最も遅く凍結すると考えられる。供試体の中央 部分が凍結する際には, 供試体の上下端面は凍結により閉塞され ているため, 間隙水の凍結に伴う体積膨張によって, 供試体の中 央部分に亀裂が発生することとなる。小玉らの実験では, これを 裏付けるように, 供試体の上下に設置されたペデスタルが凍結し 止水された直後に,「その場凍結」による変位が計測されている。 このように，小玉らは岩石を 2 方向から凍結させることで間隙水 の閉塞状態を作り出し, 亀裂が発生することを明らかにしている。 ここで用いられている凍結手法は, 岩石の中央部分で間隙水の閉 塞状態を作り出すという意味で, 三次元凍結融解実験の凍結手法 とほぼ同様のものであると考えられる。この凍結手法も, 三次元 凍結融解と同様, 幾分, 自然環境下における凍結融解とはかけ離 れた実験条件となってしまっていると考えられる。

2 つめは凍上による破懐である。小玉らは札幌軟石を用いて凍 上実験を行っているが, 札幌軟石では凍上が発生しないことを報 告している。

上記を踏まえ, 筆者らは, これまでに, 札幌軟石を含む 5 種類 の岩石を用いた一次元凍結実験を行ってきた。岩石を一次元凍結 させることで，より自然環境に近い状態で低温の影響を与えるこ とができる。この実験の結果，札幌軟石を除く 4 種類の岩石では 凍上現象が発生したものの, 小玉らと同様に, 札幌軟石では凍上 現象は発生せず，目に見えるような劣化も確認できなかった ${ }^{5) 。}$

本研究では, これまでの研究をさらにす寸めて, 1 方向からの 一次元凍結融解を繰返し行うことで, 札幌軟石がどのような挙動 を示すのか，明らかにすることに取り組んだ。札幌軟石を用いて 一次元凍結融解を繰返し行った報告例は少なく, 札幌軟石が一次 元凍結融解の繰返しでどのように劣化するのかは明らかにされ
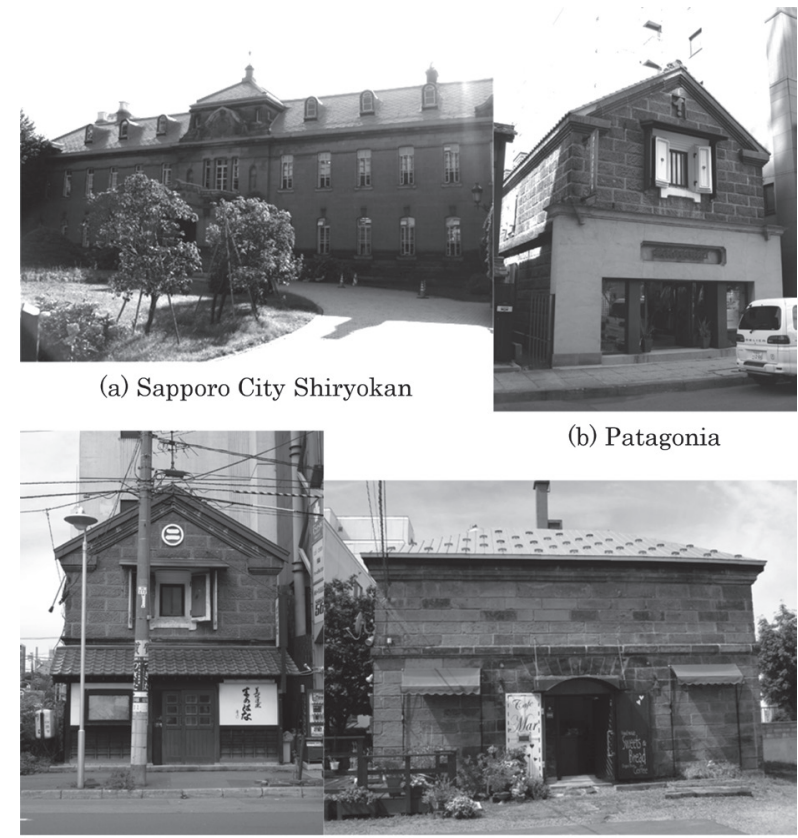

(c) Mamehana

(d) Cafe Mar

Fig.1 Photographs of Sapporo Soft Rock Architecture. (Taken by Author)

ていない。また, 本研究では, 劣化の度合いを表す指標として, $\mathrm{AE}$ (Acoustic Emission), 空隙率, 乾燥状態における弾性波速度を 用いた。表面的に劣化の現れづらい札幌軟石でも, $\mathrm{AE}$ を計測す ることによって, 岩石内部で発生する微細な破壊を詳細に解析す ることが可能になると考えられる。

本研究で明らかにした札幌軟石の 1 方向からの一次元凍結融解 による劣化メカニズムは, 歴史的な建築物として再評価されつつ ある札幌軟石建築物の維持管理手法を検討するうえで, 工学的に 非常に有意義である。

\section{2. 札幌軟石 (支笏溶結凝灰岩)}

今からおよそ 4 万年前, 後の支笏湖をつくることになる巨大な 噴火が起こり, 軽石や火山灰, 火砕流が札幌一苫小牧間の平野に 広い範囲で堆積した。このときの火砕流が冷え固まった岩石が「支 笏溶結凝死岩」である。支䇗溶結凝灰岩は札幌市南区石山付近ま で分布しており, 特に, 石山で採掘された溶結凝灰岩は「札幌軟 石」と呼ばれている。

市民グループ「札幌建築鑑賞会」と「札幌軟石文化を語る会」 が，2005 年からスタートした「札幌軟石発掘大作戦」によって, 2009 年までに, 札幌市内で約 1700 の札幌軟石物件が確認されて いる ${ }^{6)}$ 。

市街地に点在するこれらの札幌軟石建築物は, 前述したような 高見ら ${ }^{1)}$ や福田 ${ }^{2)}$ 等の報告に反して, 現在でも健全なものが多く, 今なお，公共施設や店舗として利用されているものも少なくない (Fig. 1)。

\section{3. 三次元凍結融解と一次元凍結融解の差異}

本研究では, 札幌軟石の凍結融解による劣化メカニズムを解明 する手法として, 一次元凍結融解実験を採用した。一方, 従来の 岩石の耐寒性を判定する実験方法は, 冷凍庫等を用いて, 含水飽 和状態の試料を周囲から三次元的に凍結融解させるというもので ある。そこで, 従来行われてきた三次元凍結融解実験と, 今回用 いた一次元凍結融解実験の差異を明らかにする目的で, 以下にそ 


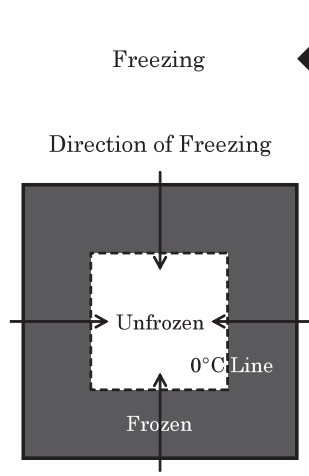

Repeat

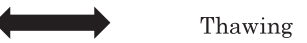

Fig.2 Schematic image of three dimensional freeze-thaw phenomenon.

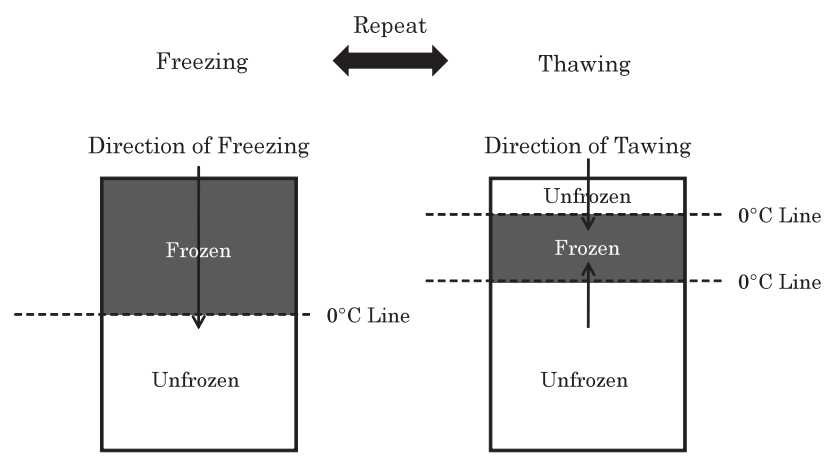

Fig.3 Schematic image of one dimensional freeze-thaw phenomenon.

れぞれの凍結融解プロセスについて示す。

一般的な三次元凍結融解実験のプロセスを, Fig. 2 に模式的に 表す。Fig. 2 に示すように, 三次元凍結融解では供試体を全面か ら泠却していく。これに伴って, 供試体内部には温度勾配が生じ, $0^{\circ} \mathrm{C}$ 線は供試体の中央部分へと移動していく。 $0^{\circ} \mathrm{C}$ 線が通過した凍 結部分では, クラックや空隙中の水分が凍結して間隙水が形成さ れる。このように三次元的に供試体を凍結させていくと, 供試体 の中央部分は最も遅く凍結することとなる。これに伴い, 最後ま で供試体の中央部分に存在する未凍結の水分は, 供試体周辺部の 凍結によって閉塞された状態となる。さらに凍結が進むと，供試 体の中央部分から外部に向かって等方的に圧力が発生することと なる。よって, 三次元凍結融解実験では, 供試体の中央部分から, 盛り上がるように, 放射状に亀裂が発生する。同様に, 融解につ いても，供試体の全面から行っていく。

本研究で想定した 1 方向からの一次元凍結融解のプロセスを, Fig. 3 に模式的に表す。Fig. 3 に示すように, 本実験では供試体 を上面から泠却していく。これに伴って, 供試体内部には温度勾 配が生じ, $0^{\circ} \mathrm{C}$ 線が熱流方向に直交して下方へと移動していく。 $0^{\circ} \mathrm{C}$ 線より上方の凍結部分では, クラックや空隙中の水分が凍結して 間隙水が形成される。この際に発生する体積膨張は, 潜在するク ラックや空隙中に, クラックを押し広げる方向の内部圧力を発生 する。やがて供試体は熱的な平衡状態に達し, $0^{\circ} \mathrm{C}$ 線は供試体の 中央部分で停滞する。数時間, $0^{\circ} \mathrm{C}$ 線を供試体中央部に留まらせ た後, 供試体を上面から融解させていく。これに伴って, $0^{\circ} \mathrm{C}$ 線 は供試体上面から下方へと移動していく。また, 供試体中央部分 に留まっていた $0^{\circ} \mathrm{C}$ 線も上方へと移動していく。2 本の $0^{\circ} \mathrm{C}$ 線が 通過した融解部分では, クラックや空隙中に形成されていた間隙 水が融解する。最終的に, 2 本の $0^{\circ} \mathrm{C}$ 線に挟まれた凍結部分が融 解すると, 供試体は完全に融解することとなる。以上のような一
Table 1 Basic physical properties.

\begin{tabular}{|c|c|c|c|c|}
\hline \multicolumn{2}{|c|}{ Test Piece } & No.4-2 & No.5-1 & No.5-2 \\
\hline \multicolumn{2}{|c|}{$\begin{array}{c}\text { Water Absorption Ratio } \\
(\%)\end{array}$} & 26.6 & 26.1 & 26.8 \\
\hline \multicolumn{2}{|c|}{ Porosity (\%) } & 36.6 & 36.2 & 36.9 \\
\hline \multicolumn{2}{|c|}{ Bulk Density } & 1.39 & 1.41 & 1.39 \\
\hline \multirow{2}{*}{$\begin{array}{c}\text { Elastic Wave } \\
\text { Velocity } \\
(\mathrm{km} / \mathrm{s})\end{array}$} & Dry & 2.12 & 2.19 & 2.19 \\
\hline & Wet & 2.27 & 2.35 & 2.34 \\
\hline
\end{tabular}

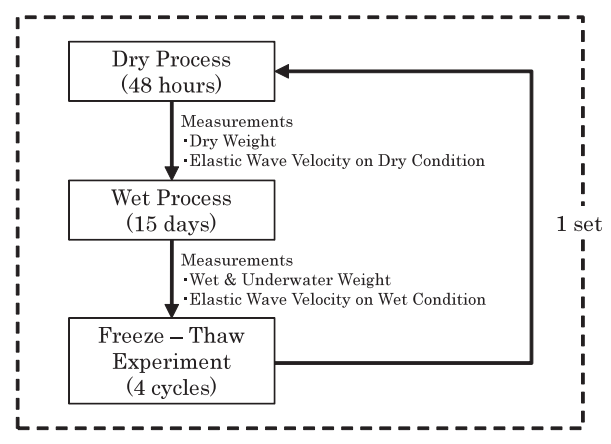

Fig.4 Flowchart of experiments.

次元の凍結融解を繰り返すことにより, 供試体内部にはダメージ が蓄積されていくと考えられる。

\section{4. 繰返し一次元凍結融解実験}

\section{$4 \cdot 1$ 供試体}

岩石ブロックの堆積面に対して垂直にボーリングを行い, 供試 体を採取した。供試体は円柱形で, その寸法は, 直径 $55 \mathrm{~mm}$, 長 さ $70 \mathrm{~mm}$ である。また, $\mathrm{AE}$ センサを設置する目的で, 供試体側 方の曲面を研磨し, 幅約 $20 \mathrm{~mm}$, 長さ約 $55 \mathrm{~mm}$ の長方形の平坦面 を整形した。このような供試体を 3 本用いて実験を行い, その再 現性を確認した。

Table 1 に，本研究で使用した 3 本の供試体の凍結融解実験前 における基本的な物性を示す。弾性波速度の測定は, 乾燥, 湿潤 状態で行っているが, 供試体の乾燥及び湿潤は以下に示寸方法で 行った。

\section{$4 \cdot 2$ 実験の流れ}

Fig. 4 に, 本研究における実験の手順を示す。乾燥状態の供試 体を蒸留水に浸して, 真空環境下で湿潤させた後, 凍結融解実験 を 4 サイクル連続で行う。この流れを 1 セットとして合計 10 セッ ト, つまり, 凍結融解を 40 サイクル行った。また, 凍結融解実 験前の乾燥, 湿潤時には, 乾燥, 湿潤状態における弾性波速度の 測定を行った。

\section{$4 \cdot 3$ 供試体の乾燥及び湿潤方法}

乾燥は, 供試体を $100^{\circ} \mathrm{C}$ オーブンに 2 日 (48 時間) 入れて行っ た。このような方法で岩石を乾燥させた場合, 供試体は絶乾状態 である。

Fig. 5 に, 本研究における供試体の湿潤手順を示す。湿潤は, 供試体を蒸留水中に入れて真空ポンプで 1 日 (24 時間) 脱気した 後, 常圧で 1 日 (24 時間) 放置した。このような真空ポンプによ る脱気を 3 度繰返した後, 供試体を常圧で 10 日間放置した。つ まり，湿潤には合計で 15 日間要することとなる。このような方 


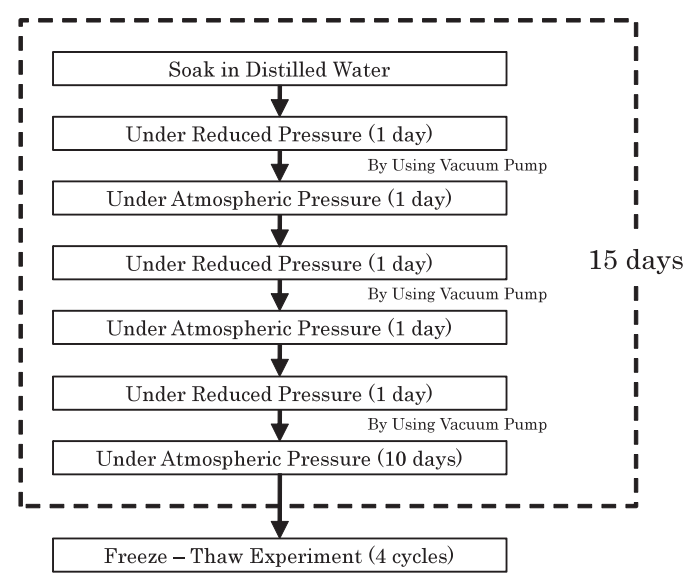

Fig.5 Flowchart of wet process.

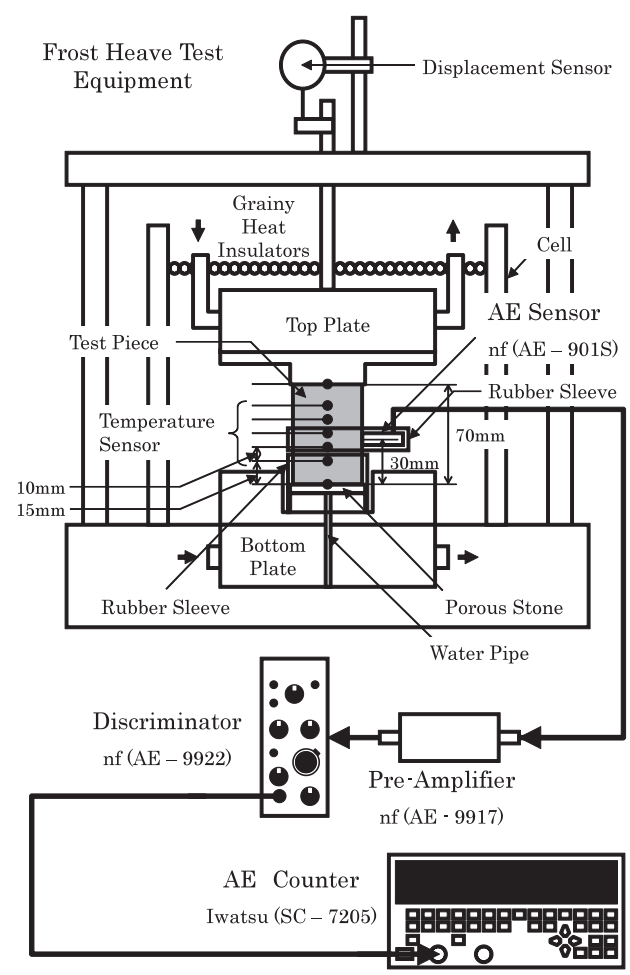

Fig.6 Frost heave experiments and $\mathrm{AE}$ measurement equipment.

法で岩石を湿潤させた場合，供試体はほぼ含水飽和状態である。

\section{$4 \cdot 4$ 岩石の凍上実験装置}

本研究で使用した岩石の凍上実験装置を Fig. 6 の上部に示す。 この実験装置を, 室温約 $+25^{\circ} \mathrm{C}$ 実験室内に設置して実験を行っ た。試験装置の詳細については, 中村ら ${ }^{5)}$ を参照されたい。

図の実験装置の上下盤を, 独立した 2 台の恒温水槽で制御する。 ただし，供試体の下には，厚さ $5 \mathrm{~mm}$ のポーラスストーンが設置 されているため, 供試体の下面温度と下盤温度は, 若干異なる温 度となってしまう。

下盤には給水管が設置されており，水分供給を行うことが可能 である。また，供試体の下にポーラスストーンを設置することに よって, 水分が供試体下面へと一様に供給されるようにした。さ らに，供試体の側面をゴムスリーブで被い，給水管を通って供給 される水分が漏れないようにした。

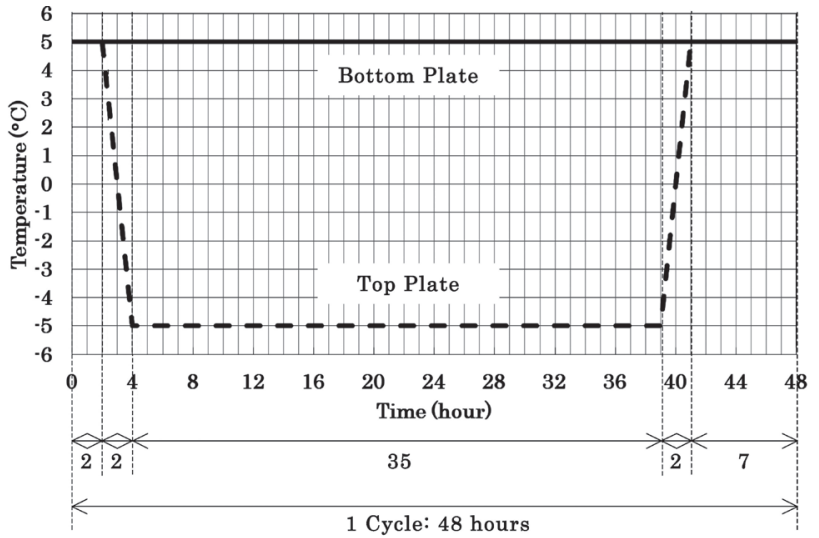

Fig.7 Temperature conditions of top and bottom plate.

供試体の側面は, セル内に充填された粒状の発砲スチロールに よって, 断熱した。このため, 室温の影響を受けずに実験を行う ことが可能である。

凍上量は装置上方の変位計によって計測される。また, 供試体 には 5 本の温度センサ (熱電対) を供試体の中央から $10 \mathrm{~mm}$ の間 隔で設置した。また，これとは別に，上下盤と供試体との境界部 分にも 2 本の温度センサ (白金抵抗体) を設置した。以上の凍上 量と温度のデータは, データロガーによって, 1 分毎に収集される。

本研究では, 上記の温度センサから得られた值と, あらかじめ ノギスを用いて計測しておいたセンサ設置位置の值を用いて, 凍 結面 $\left(0^{\circ} \mathrm{C}\right.$ 線) の位置を算出した。具体的には， $0^{\circ} \mathrm{C}$ 線を跨ぐ $2 つ$ のセンサから得られるプラスとマイナスの温度データを用いて, 凍結部分と未凍結部分の熱伝導率は考慮せずに, 単純な比例配分 で計算を行った。

\section{$4 \cdot 5$ 凍結融解時の温度設定}

実験はまず，上下盤をコントロールする冷媒の温度を+ $5^{\circ} \mathrm{C} に$ 設定し, 供試体の内部温度を $+5^{\circ} \mathrm{C}$ で一様にした。その後, 上盤 の冷媒温度を, プログラムでFig. 7 のように制御して, 凍結融解 を行った。

プログラムをスタートすると, 上下盤の冷媒温度は引き続き十 $5{ }^{\circ} \mathrm{C}$ のままで, 2 時間保持される。

凍結時, まず, 上盤の泠媒温度を 2 時間かけて $+5^{\circ} \mathrm{C}$ から $-5^{\circ} \mathrm{C}$ まで低下させていく。その後, 上盤の冷媒温度をー $5^{\circ} \mathrm{C}$ のまで 35 時間保持する。

融解時, $-5^{\circ} \mathrm{C}$ まで低下させていた上盤の冷媒温度を, 2 時間 かけて $+5^{\circ} \mathrm{C}$ ま 上昇させていく。その後, 上盤の冷媒温度を+ $5{ }^{\circ} \mathrm{C}$ のまで 7 時間保持する。

上記の凍結融解時, 下盤の冷媒温度は常に $+5^{\circ} \mathrm{C}$ で保持される。

\section{$4 \cdot 6 \mathrm{AE}$ 計測装置}

本研究で使用した AE 計測装置を Fig. 6 に示す。

供試体側面に整形した平坦面に, 共振型 $\mathrm{AE}$ センサ ( ( 株 ) nf, $\mathrm{AE}-901 \mathrm{~S}$, 共振周波数 $150 \mathrm{kHz}$ ) を直接取り付け, ゴムスリーブで 圧着した。設置位置は，供試体下面から，30 mm の位置である。

$\mathrm{AE}$ センサが取得した $\mathrm{AE}$ 信号は, プリアンプ ( (株) nf, $\mathrm{AE}-$ 9917）を用いて 40dB で増幅され，50kHzのハイパスフィルタで ノイズを除去される。

プリアンプで増幅された $\mathrm{AE}$ 信号は, さらに, ディスクリミネー

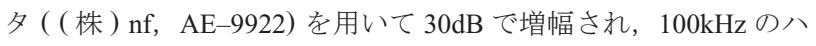
イパスフィルタ, $500 \mathrm{kHz}$ のーパスフィルタでノイズを除去さ れる。

上記の機器で, 増幅及びノイズを除去された $\mathrm{AE}$ 信号は, 最終 
Before Freeze-Thaw Cycle Experiments
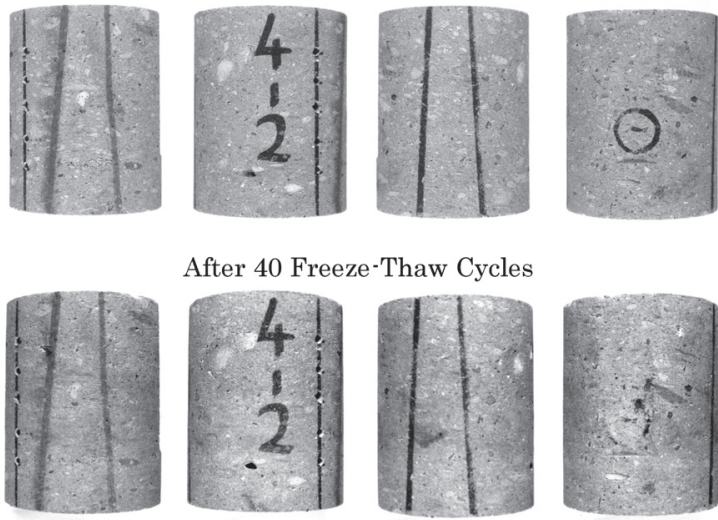

After 40 Freeze-Thaw Cycles
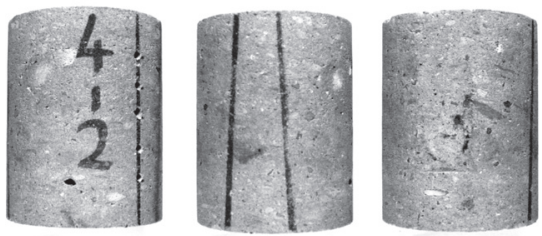

Fig.8 Appearance of test piece No.4-1 before and after 40 freeze-thaw cycles.

的に, $\mathrm{AE}$ カウンタ ( (株) 岩通, SC-7205) に入力される。 $\mathrm{AE}$ カ ウンタではしきい值を設定することが可能である。このしきい值 を用いて, 入力された $\mathrm{AE}$ 信号がしきい值を越える回数をカウン トしていく。本研究ではしきい值を $0.5 \mathrm{~V}$ に設定した。

\section{5. 実験結果と考察}

前述したように, 本研究では 3 本の供試体を用いて 1 方向から の一次元凍結融解実験を行った。用いた 3 本の供試体全てにおい て,ほぼ同様の実験結果が得られた。ここでは, 代表的な例とし て，供試体 No.4-2 の実験結果について示す。

\section{$5 \cdot 1$ 凍結融解前後の供試体}

Fig. 8 に, 凍結融解前後における乾燥状態の供試体 No.4-2 の様 子を示す。凍結融解を 40 サイクル与えているにも関わらず，表 面的には，供試体に劣化は確認できない。供試体 No.5-1, No.5-2 においても，目に見えるような劣化は確認できなかった。また， 中村ら ${ }^{5)}$ と同様, 本研究においても札幌軟石では, 凍上現象は 発生しなかった。

以上の観察から, 本研究で行った 1 方向からの一次元凍結融解 実験之, 陳ら ${ }^{3)}$ が行った三次元凍結融解実験, 小玉ら ${ }^{4)}$ が行っ た 2 方向からの一次元凍結融解実験の実験結果は大きくことなる ことは明らかである。温度条件などに違いがあるものの, 本研究 の実験結果は, 一次元と三次元とで, 岩石が受ける凍結の影響が 大きく異なることを示唆している。

\section{$5 \cdot 2$ 凍結融解 1 サイクル目における凍結面 $\left(0^{\circ} \mathrm{C}\right.$ 線 $)$ の位置 \\ と $\mathrm{AE}$ 発生数}

Fig. 9 に, 凍結融解 1 サイクル目における凍結面 (以下 $0^{\circ} \mathrm{C}$ 線) の位置を点線で, 30 分ごとの $\mathrm{AE}$ 発生数を棒グラフで示す。本 研究では, 凍結融解過程における $0^{\circ} \mathrm{C}$ 線の挙動を, 図のように 4 つのプロセスに分類した。以下，プロセスごとに， $\mathrm{AE}$ 発生数の 挙動を考察していく。

$5 \cdot 2 \cdot 1$ プロセス 1 実験を開始し, 上盤の冷媒温度を $+5^{\circ} \mathrm{C}$ から $-5^{\circ} \mathrm{C}$ 一下げていく過程において, 供試体は上面か ら泠却されていく。これに伴い $0^{\circ} \mathrm{C}$ 線の位置は, 供試体上部から 中央部分へと下がっていく。この時, 供試体は過冷却状態である ため, 岩石の間隙内部に間隙水は存在しない。その後, 図中の矢 印の位置において過冷却状態が破れ, 間隙水が凍結し始める。そ の際に発生する潜熱によって $0^{\circ} \mathrm{C}$ 線の位置は急上昇する。つまり, この $0{ }^{\circ} \mathrm{C}$ 線の上昇は, 岩石が凍結し始めたことを意味している。 本研究では, 供試体が過冷却状態を破って凍結し, $0^{\circ} \mathrm{C}$ 線の上昇 がピークを迎えるまでの過程をプロセス 1 とした。

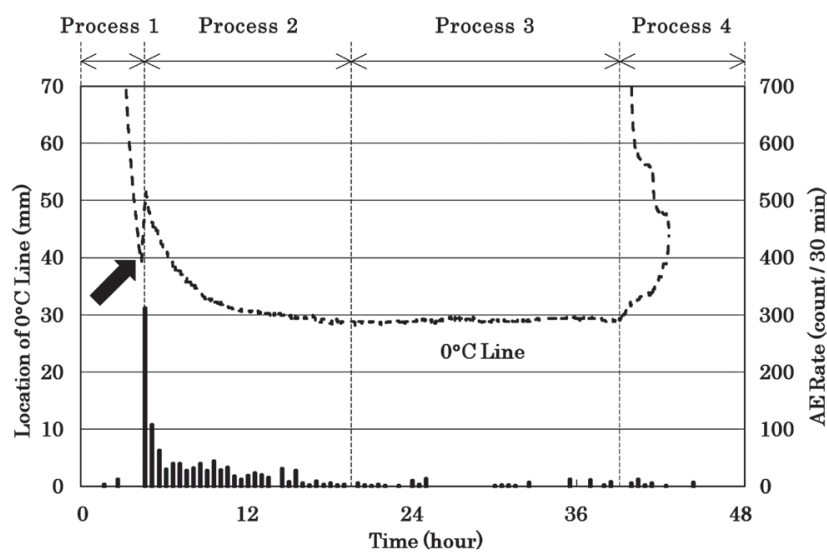

Fig.9 Location of $0^{\circ} \mathrm{C}$ line and $\mathrm{AE}$ count rate in the first freeze-thaw cycle.

Fig. 9 から, 凍結融解 1 サイクル目のプロセス 1 では, 過冷却 状態が破れる際に, 300 カウントに達する程の, 多くの $\mathrm{AE}$ が発 生していることを確認できる。これは, 過冷却状態が破れ, 間隙 水が間隙水一と相変化する際に発生する体積膨張によって, 岩石 の間隙が押し広げられ，ダメージを受けるためだと考えられる。

$5 \cdot 2 \cdot 2$ プロセス 2 上昇した $0{ }^{\circ} \mathrm{C}$ 線は再び下がり始め, 供試体の下方へと凍結が進行していく。その後， $0^{\circ} \mathrm{C}$ 線の移動は 徐々に停滞していき, 供試体が熱的な平衡状態に達すると, 最終 的に $0^{\circ} \mathrm{C}$ 線はある一定の位置から移動しなくなる。本研究では, $0^{\circ} \mathrm{C}$ 線が下方へと移動していき, 熱的な平衡状態に達して移動し なくなるまでの過程をプロセス 2 とした。

Fig. 9 から, プロセス 2 では, $0^{\circ} \mathrm{C}$ 線の移動時に, 多くの $\mathrm{AE}$ が 発生していることを確認できる。 $0^{\circ} \mathrm{C}$ 線が下方へと移動する際, $0^{\circ} \mathrm{C}$ 線より上部では間隙水がその都度形成されることとなる。このた め, 供試体中の凍結領域は拡大していき, 間隙水の量も増加して いく。AE は, この凍結領域の拡大に伴って, 発生していると考 えられる。また, $\mathrm{AE}$ 発生数は, $0^{\circ} \mathrm{C}$ 線の移動が停滞するのに従っ て, 徐々に減少していく。

$5 \cdot 2 \cdot 3$ プロセス 3 供試体は熱的な平衡状態に達してい るため, $0^{\circ} \mathrm{C}$ 線の移動は起こらない。本研究では, この供試体が 熱的な平衡状態に保たれている過程をプロセス 3 とした。

Fig. 9 から, プロセス 3 の $\mathrm{AE}$ 発生数は, ごく僅かであること が確認できる。これは $0^{\circ} \mathrm{C}$ 線が移動せず, 供試体中に新たな間隙 水が形成されないためだと考えられる。

$5 \cdot 2 \cdot 4$ プロセス 4 上盤の冷媒温度を $-5^{\circ} \mathrm{C}$ から $+5^{\circ} \mathrm{C} に$ 上げ，供試体を融解させていく。この際，供試体は上面から暖め られるため, $0^{\circ} \mathrm{C}$ 線は供試体上部から中央部分一と移動していく。 また, 冷却時に供試体の中央部分へと進行していた $0^{\circ} \mathrm{C}$ 線も, 供 試体の融解と共に上昇していく。

Fig. 9 から, プロセス 4 では, 供試体の融解時に, 微少ではあるが, $\mathrm{AE}$ が発生していることを確認できる。これは，間隙中に形成さ れていた間隙水が水一相変化することで体積減少を起こし，押し 広げられていた岩石の間隙が収縮したためだと考えられる。

\section{$5 \cdot 3$ 凍結融解 1 サイクル目における $0^{\circ} \mathrm{C}$ 線の位置と供試体の}

\section{鉛直変位量}

Fig. 10 に, 凍結融解 1 サイクル目における $0^{\circ} \mathrm{C}$ 線の位置を点 線で，供試体の鉛直変位量を実線で示す。

図から, 冷却時における供試体の収縮, 凍結時における膨張, 融解時における収縮を確認することができる。ただし，これらの 変位は非常に小さい。これは, 凍結融解 1 サイクル目の供試体は 


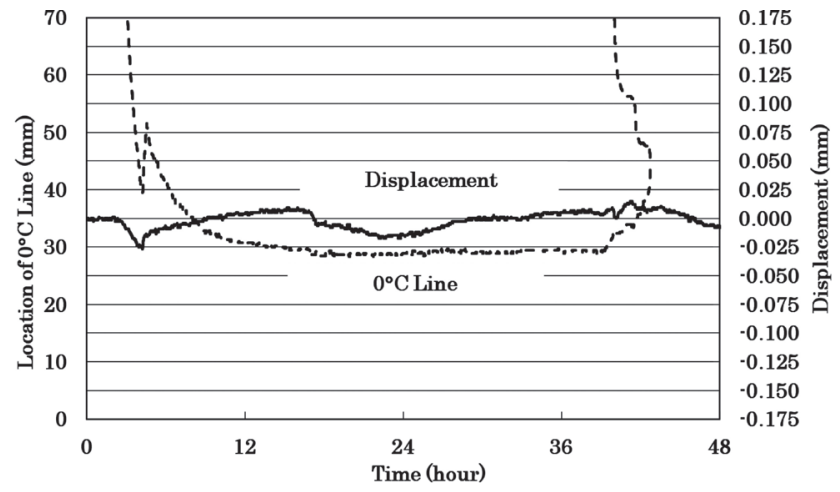

Fig. 10 Location of $0^{\circ} \mathrm{C}$ line and displacement in the first freeze-thaw cycle.

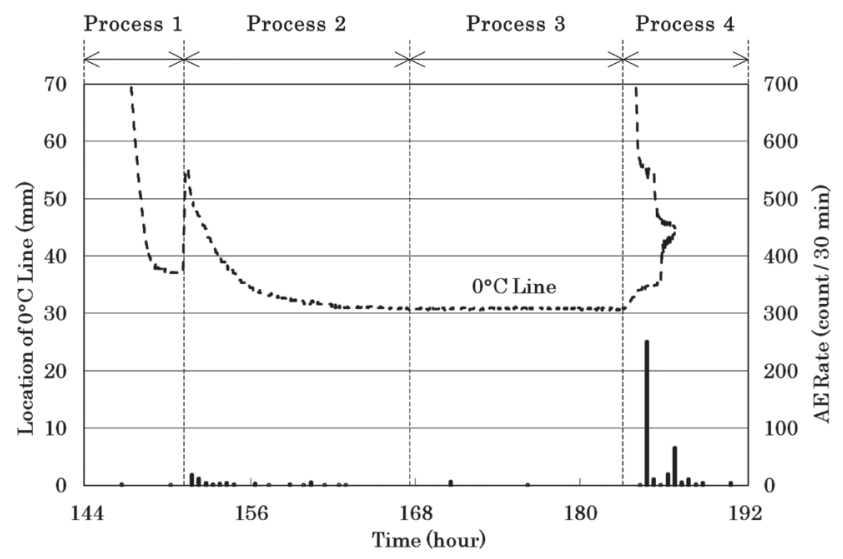

Fig. 11 Location of $0^{\circ} \mathrm{C}$ line and $\mathrm{AE}$ count rate in the 40th freeze-thaw cycle.

凍結融解作用を受けておらず, 新鮮で, 強度が高いためだと考え られる。

\section{$5 \cdot 4$ 凍結融解 40 サイクル目における $0^{\circ} \mathrm{C}$ 線の位置と $\mathrm{AE}$ 発} 生数

Fig. 11 に，凍結融解 40 サイクル目における $0{ }^{\circ} \mathrm{C}$ 線の位置を点 線で, 30 分ごとの $\mathrm{AE}$ 発生数を棒グラフで示す。

図から，凍結融解 40 サイクル目のプロセス 1 , プロセス 2 の $\mathrm{AE}$ 発生数は, Fig. 6 に示した凍結融解 1 サイクル目のそれに比 べて, 非常に少ないことが明らかである。この原因については, 以下の「5・6 凍結融解サイクル数と $\mathrm{AE}$ 発生数, 供試体の鉛直 変位量」で詳述する。

一方, プロセス 4 では, 250 カウントに達する程の, 多くの $\mathrm{AE}$ が発生していることを確認できる。このことから, 融解時に おける $\mathrm{AE}$ 発生数が, 凍結融解 1 サイクル目に比べて, 非常に多 いことは明らかである。この原因については, 以下の「5・5 凍 結融解 40 サイクル目における $0^{\circ} \mathrm{C}$ 線の位置と供試体の鉛直変位 量」で詳述する。

また, プロセス 3 の $\mathrm{AE}$ 発生数は, 凍結融解 1 サイクル目と同 様, ごく僅かである。

\section{$5 \cdot 5$ 凍結融解 40 サイクル目における $0^{\circ} \mathrm{C}$ 線の位置と供試体} の鉛直変位量

Fig. 12 に, 凍結融解 40 サイクル目における $0^{\circ} \mathrm{C}$ 線の位置を点 線で，供試体の鉛直変位量を実線で示す。

図から, 凍結融解 1 サイクル目と同様に, 冷却時における供試 体の収縮, 凍結時における膨張, 融解時における収縮を確認寸る ことができる。凍結時における膨張と融解時における収縮による 変位は, 凍結融解 1 サイクル目に比べて, 1 オーダーほど大きい。

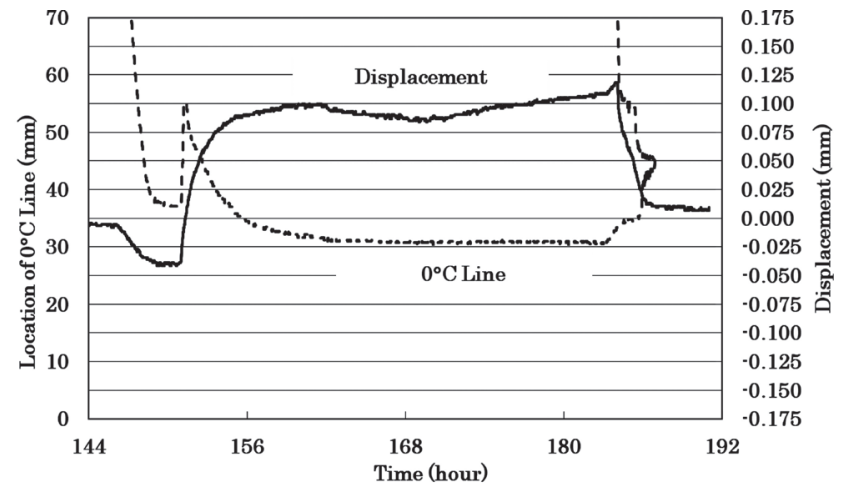

Fig.12 Location of $0^{\circ} \mathrm{C}$ line and displacement in the 40 th freeze-thaw cycle.

このことから, 凍結融解 40 サイクル目の供試体は, 凍結融解作 用を受けて強度が低下し, 変形し易くなっているのではないかと 推測できる。Fig. 11 に示したように, 凍結融解 40 サイクル目の プロセス 4 では多くの $\mathrm{AE}$ が発生しているが，これは上記の融解 時における大きな変位に起因すると考えられる。

\section{$5 \cdot 6$ 凍結融解サイクル数と $A E$ 発生数, 供試体の鉛直変位量}

Fig. 13 に, 凍結融解サイクル数と各プロセスにおける $\mathrm{AE}$ 発 生数との関係を示す。図の各プロセスにおける $\mathrm{AE}$ 発生数の和は, 各サイクルにおける総 $\mathrm{AE}$ 発生数を表しており, 図中の点線は, 総 $\mathrm{AE}$ 発生数の傾向を模式的に表したものである。また, 凍結融 解 39 サイクル目では，AEがほとんど発生していないが，これ は39サイクル目のみ, 過冷却が破れずに凍結融解サイクルが終 了したためである。

各凍結融解サイクルにおける総 $\mathrm{AE}$ 発生数に着目すると, 総 $\mathrm{AE}$ 発生数は凍結融解 1 サイクル目で多く, その後, 減少してい く傾向を見て取ることができる。しかしながら，極端に多くの $\mathrm{AE}$ が発生しているサイクルがあるものの, 最終的に総 $\mathrm{AE}$ 発生 数はほぼ一定の值に収束していく傾向にあると考えられる。凍結 融解サイクルを重祆ても, AE はコンスタントに発生し続けてい ることから, 供試体は徐々にではあるが劣化し続けているものと 考えられる。

プロセス 1 の $\mathrm{AE}$ 発生数は, 凍結融解 1 サイクル目に最も多く, そこから減少し, 最終的に発生数は限りなくゼロに近くなる。また, プロセス 2 にいても, 凍結融解サイクルを重ねるごとに $\mathrm{AE}$ 発 生数が減少していく傾向を見て取れる。この原因については, 以 下のように考えた。

岩石は不均一材料であるため, 供試体中に, 低強度部分と高強 度部分が存在すると仮定する。まず, 凍結融解サイクル数が少な い実験の初期段階では, $\mathrm{AE} の$ 発生は, 亀裂の発生, 伸展が容易 な, 供試体の低強度部分で起こると考えられる。その後, 凍結融 解サイクルを重礼ていくと, 亀裂の発生, 伸展は, 低強度部分か ら, より高強度部分へとシフトしていく。強度が高くなるにつれ て亀裂は発生, 伸展しにくくなるため, これに伴い, プロセス 1 , 2 における AE 発生数は減少していくものと考えられる。

プロセス 4 の $\mathrm{AE}$ 発生数は, 凍結融解サイクルを重祃るごとに 増加する傾向を示している。これは供試体内部の劣化が進み, 間 隙水が押し広げるクラックの体積が大きくなることで, 融解時に おける間隙の収縮が大きくなるためだと考えられる。以下に示す Fig. 14 は，この考察を裏付ける結果となっている。

Fig. 14 に, 凍結融解サイクル数と各サイクルにおける供試体の 鉛直変位量との関係を示す。図中の棒グラフは, 供試体が膨張し た場合には正の值を, 収縮した場合には負の值を示している。先 
の章で既に述べているが，供試体の鉛直変位は， 冷却時に収縮, 凍結時に膨張, 融解時に収縮を 示す。凍結融解 39 サイクル目では, 融解時に 膨張を示しているが,これは39サイクル目のみ, 過冷却が破れず供試体が凍結しなかったためで ある。

図から, 凍結時の膨張量及び融解時の収縮量 が，凍結融解サイクルを重秝るごとに，増大し 続けていることを確認することができる。一方， 冷却時における供試体の収縮量は凍結融解を重 ねても変化がなく, ほぼ一定の值 (約 $0.036 \mathrm{~mm}$ ) を示している。

\section{$5 \cdot 7$ 凍結融解サイクル数と空隙率及び弾性} 波速度

Fig. 15 に，凍結融解サイクル数と各サイクル における供試体の空隙率及び乾燥状態における 弾性波速度との関係を示す。図には，本研究に 用いた 3 本の供試体，全ての実験結果を示した。

図から, 凍結融解サイクルを重㸚ることで, 弾性波速度が減少し続けていることを確認する ことができる。また，空隙率も弾性波速度と同 様に，多少のばらつきが見られるものの，凍結 融解サイクルを重衫ることで増加していく傾向 を見て取ることができる。

前章「5.6 凍結融解サイクル数と $\mathrm{AE}$ 発生数, 供試体の鉛直変位量」で既に述べているが，総 $\mathrm{AE}$ 発生数から確認されたように，供試体は凍結 融解サイクルを重ねることで, 徐々ではあるが劣 化していることが，空隙率及び弾性波速度からも 確認することができた。

\section{6. 札幌軟石の一次元凍結融解による 劣化メカニズム}

本研究で得られた実験結果をもとに，札幌軟 石の一次元凍結融解による劣化メカニズムを, 以下のように考えた。

(1) 凍結 (プロセス 1)

冬期，岩石は表面から泠却されていく。これ に伴い $0^{\circ} \mathrm{C}$ 線は，表面部分から深部方向へと移 動していく。この時, 岩石は過冷却状態である ため，岩石の間隙内部に間隙氷は存在しない。 その後, ある時点で過冷却状態が破れ, 凍結し 始める。その際に発生する潜熱によって $0^{\circ} \mathrm{C}$ 線 の位置は表面方向へと移動する。

過冷却状態が破れ岩石が凍結する際，岩石中 には多くの亀裂が発生していると考えられる。 これは，過冷却状態が破れ，間隙水が間隙水一 と相変化することで体積が膨張し，岩石の間隙 が押し広げられるためである。ただし, 中村ら 5) が報告しているように，空隙半径が大きく，透 水性の高い札幌軟石では, 間隙中で発生した凍結に伴う内部圧力 は, 間隙水を未凍結の深部へと移動させてしまう。この場合, 内 部圧力は岩石に作用しないため, 割裂は起こりづらいと考えられ る。

（2）凍結に伴う $0^{\circ} \mathrm{C}$ 線の移動（プロセス 2)

表面方向へと移動した $0^{\circ} \mathrm{C}$ 線は再び移動し始め, 岩石の深部方

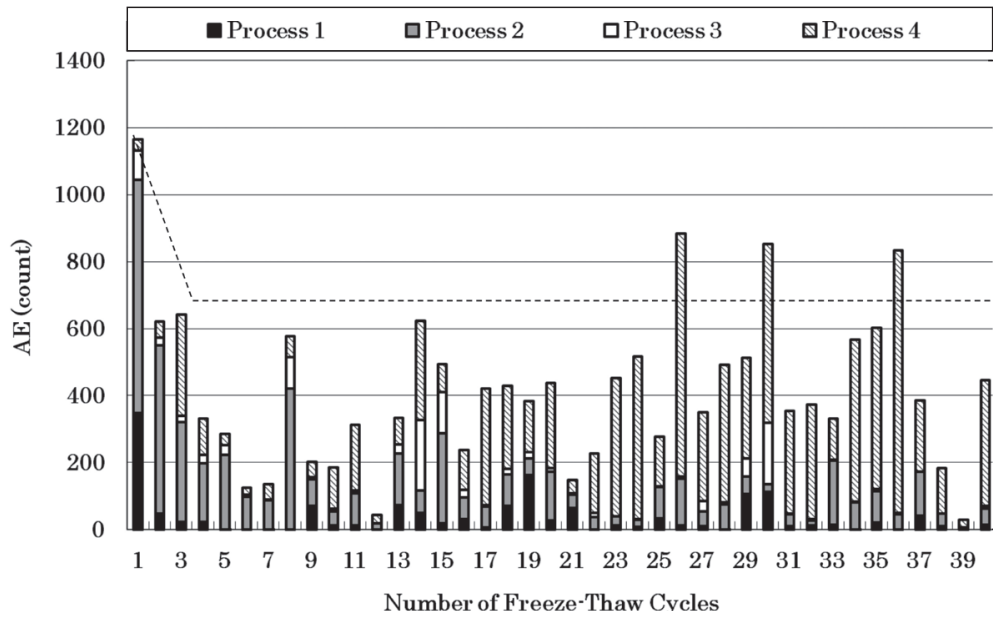

Fig.13 Number of freeze-thaw cycles and AE count in each process.

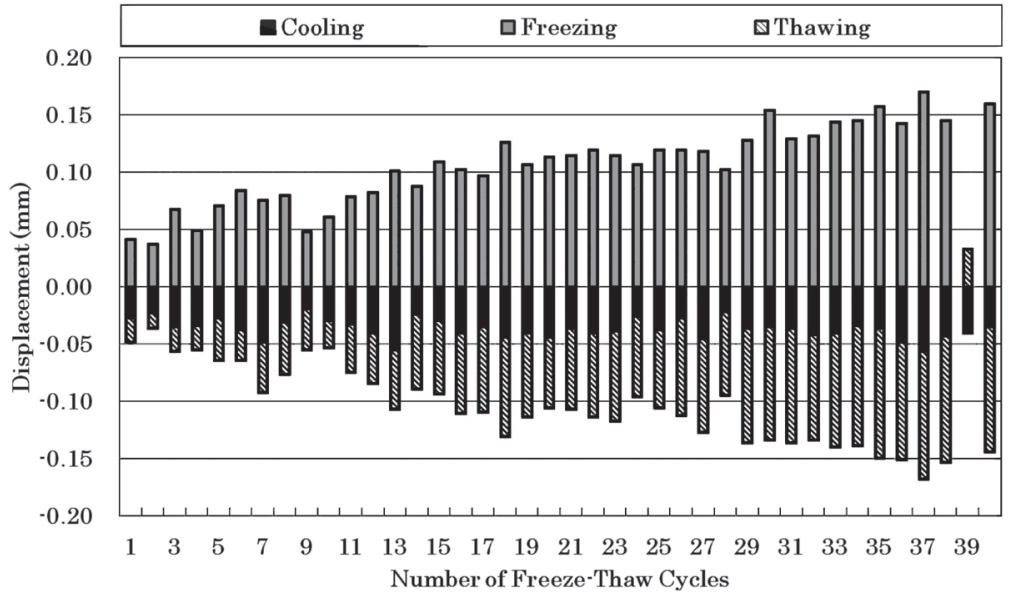

Fig.14 Number of freeze-thaw cycles and displacement.

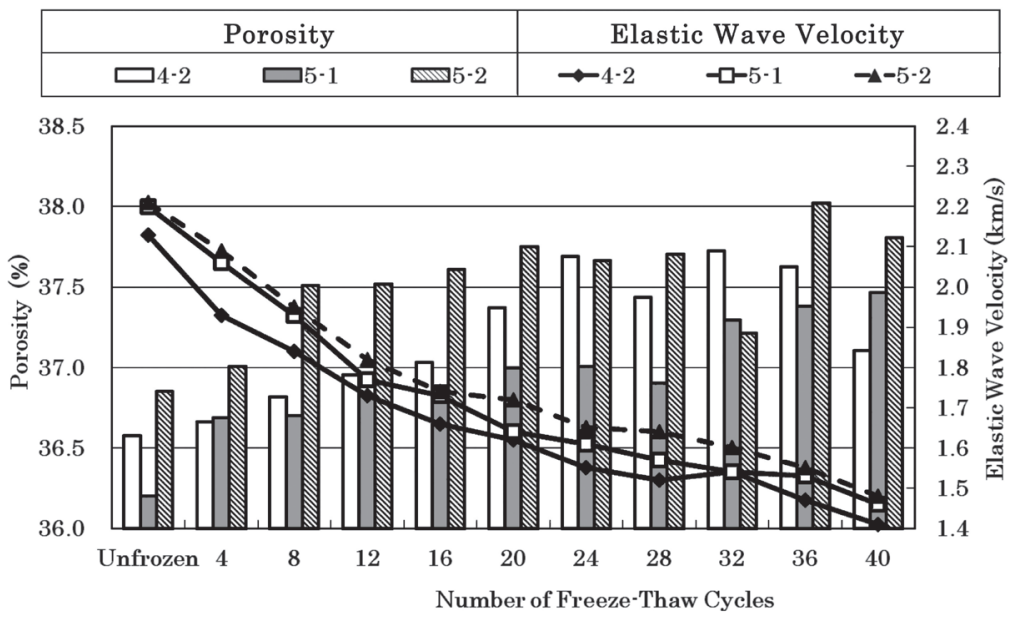

Fig.15 Number of freeze-thaw cycles and porosity and elastic wave velocity

向一と凍結が進行していく。その後, $0^{\circ} \mathrm{C}$ 線の移動は徐々に停滞 していき, 岩石が熱的な平衡状態に達すると, 最終的に $0^{\circ} \mathrm{C}$ 線は ある一定の位置から移動しなくなる。

$0^{\circ} \mathrm{C}$ 線が深部方向へと移動する際， $0^{\circ} \mathrm{C}$ 線が通過した部分では間 隙水がその都度形成されることとなる。このため, 岩石中の凍結 領域は拡大していき, 間隙水の量も増加していく。亀裂の発生, 
伸展は, この凍結領域の拡大に伴って, 起こっていると考えられる。 また, 亀裂の発生, 伸展は, 凍結融解回数の少ない初期段階では, 岩石の低強度部分において起こると考えられる。その後, 凍結融 解を重ねていくと, 亀裂の発生, 伸展は, 低強度部分から, より 高強度部分へとシフトしていく。このため, 凍結融解を繰返し受 けていくと, 岩石中の亀裂の発生量は, 徐々に減少していくこと となる。

（3）熱的な平衡状態に伴う $0^{\circ} \mathrm{C}$ 線の停滞 (プロセス 3)

岩石は熱的な平衡状態に達しているため， $0^{\circ} \mathrm{C}$ 線の移動は起こ らない。このため，岩石中には新たな間隙水が形成されず，亀裂 の発生，伸展も起こらない。

（4）融解（プロセス 4)

岩石は表面から暖められ， $0^{\circ} \mathrm{C}$ 線は表面部分から深部方向へと 移動していく。また，冷却時に岩石の深部方向へと進行していた $0{ }^{\circ} \mathrm{C}$ 線も, 岩石の融解と共に表面部分へと移動していく。この際, 間隙中に形成されていた間隙水は水一相変化する。これに伴い, 体積は減少し，押し広げられていた岩石の間隙は収縮する。

凍結融解を繰返し受けることで，岩石内部では劣化が進み，間 隙水が押し広げるクラックの体積が大きくなっていく。このため, 融解時における間隙の収縮量も大きくなっていく。

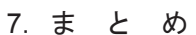

本研究では，含水飽和状態の供試体を用いて，1 方向からの一 次元凍結融解実験を 40 サイクル行った。

以下に，本研究で得られた新たな知見を示す。

(1) 1 方向からの一次元凍結融解実験を 40 サイクル行ったもの の，表面的には，供試体に劣化は確認できなかった。この実験結 果は, 一次元と三次元とで, 岩石が受ける凍結の影響が大きく異 なることを示唆している。
(2) 総 $\mathrm{AE}$ 発生数は凍結融解 1 サイクル目で多く, その後, 減少 していく傾向を見て取ることができた。しかしながら，最終的に 総 $\mathrm{AE}$ 発生数はほぼ一定の值に収束していく傾向が見てとれた。

（3）凍結融解少イクルを重ねると，凍結時 (プロセス 1，2，3) における $\mathrm{AE}$ 発生数は減少していくが，融解時 (プロセス 4) にお ける $\mathrm{AE}$ 発生数は増加していくことが確認された。

(4) 凍結時の膨張量及び融解時の収縮量は, 凍結融解サイクル を重ねるごとに，増大していくことが確認された。上記の融解時 における $\mathrm{AE}$ 発生数の増加は, この融解時における収縮量の増加 に起因する。

（5）空隙率及び乾燥状態における弾性波速度の測定結果からも, $\mathrm{AE}$ と同様に，供試体の劣化を確認することができた。

以上のように, 札幌軟石供試体を 1 方向からの一次元凍結融解 環境下に置くと，供試体内部において，劣化が進んでいくことが， $\mathrm{AE}$, 空隙率, 弾性波速度の測定結果から明らかとなった。ただし, これらの劣化は，三次元凍結融解に比べると緩やかで，目視でき る程顕著ではない。札幌軟石建築物に現在でも健全なものが多い のは, この 1 方向からの一次元凍結融解環境下で劣化しづらい性 質に起因するかもしれない。

今後, 一次元と三次元の凍結融解による岩石の劣化特性の差異 を明らかにしていくことは重要であると考えられる。

\section{References}

1) M. Takami and T. Ishizaki : Reports of Grants-in-Aid for Scientific Research (2002), pp. 1-23. 2) M. Fukuda : Sekizo Bunkazai no Hozon to Shufuku, (Tokyo Kokuritu Bunkazai Kenkyusho (1985), pp. 41-46.

3) T. Chen, N. Mori, T. Goto, T. Suzuki, M. Hiramatsu : Journal of MMIJ, 116 (2000), 7-12.

4) N. Kodama, Y Fujii, S. Akagawa, Y. Ishijima : Doboku Gakkai Ronbunshuu C (2007), Vol.63, No.1, pp.24-33.

5) D. Nakamura, T. Goto, T. Suzuki, Y. Ito and S. Yamashita : Journal of MMIJ, 124 (2008), 231-239.

6) Waga Machi no Bunka Isan Sapporo Soft Rock, (Sapporo Kenchiku Kansho Kai, Sapporo, 